\title{
Effect of the Addition of Soy Lecithin and Yucca schidigera Extract on the Properties of Gelatin and Glycerol Based Biodegradable Films
}

\author{
Tatiana P. Dias, Carlos R. F. Grosso \\ Departamento de Alimentos e Nutrição, Faculdade de Engenharia de Alimentos, UNICAMP, Brazil \\ Caroline Andreuccetti \\ Departamento de Fitotecnia, Tecnologia de Alimentos e Sócio-Economia, UNESP, Brazil \\ Rosemary A. de Carvalho \\ Departamento de Engenharia de Alimentos - ZEA, USP, Brazil \\ Tomás Galicia-García, Fernando Martinez-Bustos \\ CINVESTAV-Unidad Querétaro, Querétaro, Mexico
}

\begin{abstract}
Gelatin-based films containing soy lecithin or Yucca schidigera extract and glycerol as plasticizer were produced by casting and characterized for their mechanical properties, water vapor permeability (WVP), water solubility, opacity and morphology. The addition of glycerol reduced the tensile strength, with a difference of $\sim 68 \%$ between the values for the minimum and maximum concentrations evaluated, both for the plasticizer and the surfactant. Elongation values reached $52 \%$ and $40 \%$, for films containing yucca extract and lecithin, respectively, when higher amounts of plasticizer and surfactant were added. Lower values of WVP were obtained when the intermediate concentration of glycerol (20 g plasticizer/100 g protein) was used, reaching 0.14 and $0.15 \mathrm{~g} \mathrm{~mm} / \mathrm{m}^{2} \mathrm{~h} \mathrm{kPa}$, respectively, for films containing yucca extract and lecithin. The solubility was not affected by adding plasticizer and / or surfactants. The morphologies of the inner sections of the films, regardless of type of surfactant used, were compact, without pores or phase separation, indicating efficient incorporation of the compounds added to the protein matrix.
\end{abstract}

Keywords: Surfactants, saponin, functional properties, protein based-film.

\section{Introduction}

Films based on natural macromolecules reduce waste disposal in the environment and the macromolecules sources are renewable and easy to obtain ${ }^{[1]}$. Among the macromolecules used in film production, proteins are widely used due to their functional properties and the variety of available sources and low production cost, including caseinates, whey protein, wheat gluten and gelatin $^{[2-5]}$.

Films based on gelatin have good tensile strength and good gas barrier properties, however, due to its hydrophilic nature, they are not efficient as barrier to water vapor. Additionally, the formation of films by solvent evaporation produce an increase of interactions between the protein chains, resulting in rigid films ${ }^{[6]}$. To increase the flexibility of the films, plasticizers agents are added, generally with hydrophilic character, promoting the reduction of intermolecular forces and increase on the mobility of polymeric chains. Consequently, its extensibility increases, however, contribute negatively to also an increase on water vapor permeability of the films ${ }^{[7,8]}$.

Surfactants are amphiphilic molecules containing a hydrophobic portion that may produce a decrease on water vapor permeability of hydrophilic films. Soy lecithin is classified as a natural zwitterionic surfactant, and applications of this surfactant include emulsification and film formation ${ }^{[9]}$. Saponins are soluble in water and have in its structure a steroidal hydrophobic portion or triterpenoid and one or more carbohydrates chains, being considered as surfactants agents ${ }^{[10]}$. This feature ensures functionality in reducing surface tension of water, with consequent action as detergent, emulsifying and foaming, so it is widely used in food and other industrial applications ${ }^{[10]}$. Many sources of saponins have been used commercially, but only two are currently permitted as additives in foods: Quillaya saponaria and Yucca Schidigera extracts. They are classified as GRAS (Generally Recognized As Safe) approved by the US Food and Drug Administration as a food additive with a wide commercial application ${ }^{[10,11]}$. In addition, yucca extract contains steroidal saponins, a percentage of approximately $10 \%$, and phenolic constituents, like resveratrol with antioxidant activity, also included in the structure yaccaols, characterized by unusual spiro structures, probably derived from a flavonoid skeleton, and a stilbenic portion linked via a $\gamma$-lactone ring ${ }^{[11-14]}$. Yucca Schidigera grows in Baja California in Mexico as well and in southwestern Nevada and Arizona and central and southern California in the U.S., known as the Mojave Desert ${ }^{[11,14]}$. The branches are harvested

Corresponding author: Rosemary A. de Carvalho, Departamento de Engenharia de Alimentos - ZEA, Faculdade de Zootecnia e Engenharia de Alimentos - FZEA, Universidade de São Paulo - USP, Avenida Duque de Caxias Norte, 225, CEP 13635-900,

Pirassununga, SP, Brasil, e-mail: rosecarvalho@usp.br 
mature and processed. Are first milled and the resulting solid is dried and processed into powder or mechanically pressed and thermally condensed juice (yucca extract). The concentrate liquid is used in industry refrigerant as flavoring and foaming agent, and in the cosmetic and pharmaceutical industry is used how surfactant and preservative, due to antioxidant activity. The dry powder is the form used for animal feed ${ }^{[11-14]}$.

Andreuccetti et al. ${ }^{[15,16]}$ produced films based on gelatin containing hydrophobic plasticizers derived from citric acid and natural surfactants (lecithin or Yucca schidigera extract), by casting. The films showed good mechanical resistance and low permeability to water vapor, however in the formulations studied, the elongation was low indicating that the plasticizers, or surfactants, have not been properly incorporated into the protein matrix, producing films with low elongation values.

Considering the possibility of increasing elongation while maintaining good barrier to water vapor, this study aimed to evaluate the effect of adding natural surfactants, soy lecithin or Yucca schidigera extract, on the functional characteristics of films produced with gelatin associated with glycerol as plasticizer.

\section{Materials and Methods}

\section{Raw materials}

The following materials were used to produce the films: type A pig hide gelatin (260 bloom) donated by Gelita do Brasil Ltda (São Paulo, SP, Brazil), soy lecithin, Lécet 150M E322, lot LF 1130805T03 donated by Caramuru (São Simão, GO, Brazil), liquid Yucca schidigera extract (Extratonina Food, lot Y-4468) donated by Beraca Sabará Químicos e Ingredientes Ltda. (São Paulo, SP, Brazil), containing $10 \%$ of steroidal type saponins, as informed by the manufacturer, and glycerol as plasticizer (Ecibra, São Paulo, SP, Brazil).

\section{Preparation of biodegradable films}

The films were prepared by casting using a fixed gelatin concentration of $4 \mathrm{~g} / 100 \mathrm{~g}$ of film-forming solution. The surfactants (soy lecithin or $Y$. schidigera extract) were added in concentrations of 10,20 and $30 \mathrm{~g}$ of surfactant/100 g of glycerol and the plasticizer was added at concentrations of 10,20 and $30 \mathrm{~g}$ of glycerol/100 $\mathrm{g}$ of protein. For the preparation of the film-forming solution, the gelatin was hydrated at room temperature $\left(25 \pm 2{ }^{\circ} \mathrm{C}\right)$ for 30 minutes, followed by dissolution at $55{ }^{\circ} \mathrm{C}$ for 15 minutes. The lecithin was dissolved in ethanol (20 mL/100 $\mathrm{g}$ of filmogenic solution) and maintained under magnetic stirring ( 2 hours, room temperature). The yucca extract was dissolved in distilled water (20 mL/100 g of filmogenic solution) at room temperature, and then mixed manually. Glycerol was added and the film forming solution (gelatin + surfactant + plasticizer) homogenized at $10,000 \mathrm{rpm}$ for 1 minute using a homogenizer (UltraTurrax IKA, T18, Werke, Germany). The filmogenic solution obtained was dispersed on acrylic glass plates (14 cm diameter) and maintained at room temperature to dry. The time require to dry the films was visually determined to obtain an easy peeling from the plates and it was approximately of 12 hours. After drying and before characterization, films were maintained in desiccators $\left(25 \pm 2{ }^{\circ} \mathrm{C}, 50 \pm 2 \% \mathrm{RH}, \mathrm{Mg}\left(\mathrm{NO}_{3}\right)_{2} 6\right.$ $\mathrm{H}_{2} \mathrm{O}$ ) for 3 days. The film thickness was determined using a Mytutoyo Corp. digital micrometer (Tokyo, Japan), by calculating the average of 10 random measurements.

\section{Mechanical properties}

The tensile strength (TS, MPa) and percent elongation (E, \%) of the films (100 X $25 \mathrm{~mm}$ samples) were determined using a TA-XT2 texturometer (TA Instruments, Newcastle, USA) according to the ASTM D882-95 method ${ }^{[17]}$ with 10 replicates. The initial distance of separation and velocity were adjusted to $50 \mathrm{~mm}$ and $1 \mathrm{~mm} / \mathrm{s}$ respectively, with a $5 \mathrm{~kg}$ load cell.

\section{Water vapor permeability}

The water vapor permeability $\left(\mathrm{g} \mathrm{mm} / \mathrm{m}^{2} \mathrm{~h} \mathrm{kPa}\right)$ was determined at $25 \pm 2{ }^{\circ} \mathrm{C}$ according to the ASTM E96-95 method $^{[18]}$. All the determinations were made in triplicate. The cells were filled with anhydrous calcium chloride ( $0 \% \mathrm{RH})$, covered with the conditioned films, sealed and placed in desiccators containing a saturated $\mathrm{NaCl}$ solution $(75 \pm 3 \% \mathrm{RH})$. The samples were weighed five times during a period of 48 hours, and the data were recorded on a graph of weight gain versus time. The slope of the straight line obtained by linear regression was determined, and the WVP calculated using Equation 1.

$$
\mathrm{WVP}=\frac{w x}{t A P_{o}\left(R H_{1}-R H_{2}\right)}
$$

Where $(\mathrm{w} / \mathrm{t})$ is the slope of the linear regression line, (x) is the average thickness of the material (mm), (A) is the permeation area $\left(\mathrm{m}^{2}\right),(\mathrm{Po})$ is the water vapor partial pressure at $25{ }^{\circ} \mathrm{C}(\mathrm{kPa})$ and $\left(\mathrm{RH}_{1}-\mathrm{RH}_{2}\right)$ is the relative humidity gradient.

\section{Water solubility and moisture content}

Solubility of the films ( $2 \mathrm{~cm}$ discs) was determined according to the method of Gontard et al. ${ }^{[19]}$ after 24 hours of immersion in distilled water $(50 \mathrm{~mL})$, with slow stirring (Shaker Marconi-MA141, São Paulo, Brazil) and at room temperature $\left(25 \pm 2{ }^{\circ} \mathrm{C}\right)$. Samples were then removed from the solution and dried in a forced air oven $\left(105^{\circ} \mathrm{C}\right.$, 24 hours). The initial mass was determined from the sample moisture (gravimetric analysis) and the difference in weight used to calculate the water-soluble matter as a percentage of the initial weight. All determinations were made in triplicate.

\section{Opacity and $b^{*}$ value}

The film opacity was determined using a Hunterlab colorimeter (COLORQUEST II, Reston, VA, USA) according to the ASTM D 523 method $^{[20]}$, using a D65 daylight source. The determinations were carried out in triplicate after calibration of the equipment using standard black and white backgrounds. Opacity was determined according to Equation 2. 


$$
\mathrm{Op}=\frac{O_{p b}}{O_{p W}} 100
$$

Where Op representing the percent opacity of the film, $\mathrm{O}_{\mathrm{pb}}$ representing the opacity of the film against a black background, and $\mathrm{O}_{\mathrm{pw}}$ representing the opacity of the film against a white background. The Hunter parameter $b^{*}\left(-b^{*}\right.$, blueness to $+\mathrm{b}^{*}$, yellowness) was measured according to the standard test method ASTM D $1925^{[21]}$ in, at least, three positions randomly selected for each sample.

\section{Scanning electron microscopy}

The films were conditioned in desiccators containing silica gel $\left(25^{\circ} \mathrm{C}\right)$ for a period of 7 days and then fractured in liquid nitrogen. The fractured samples were coated with gold in a POLARON SC7620 sputter coater (Ringmer, UK) at 3 to $5 \mathrm{~mA}$ for 180 seconds, and morphological observations of the film surface and internal structure were carried out using a LEO 440i scanning electron microscope (Cambridge, UK) at $5 \mathrm{kV}$.

\section{Statistical analysis}

The statistical analysis was carried out using SAS for Windows Version 8.0 (Cary, N.C., USA) and the differences between the means determined using Tukey multiple tests at a $95 \%$ confidence level.

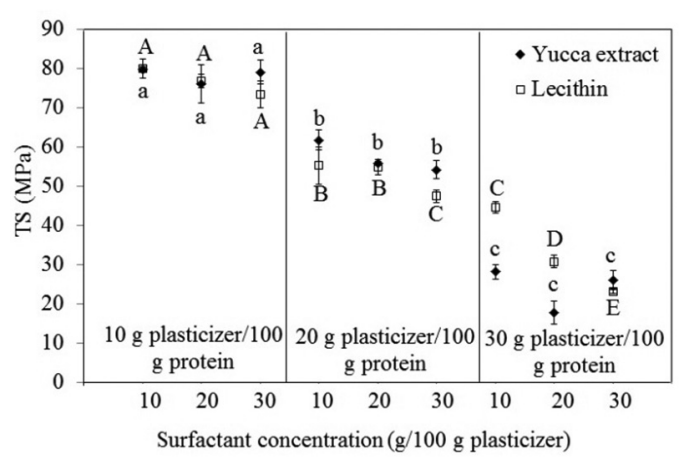

Figure 1. Effect of surfactants and plasticizer concentrations on the Tensile Strength (TS) of gelatin-based films. Averages followed by lowercase letters and capital letters represent significant differences $(p \leq 0.05)$, for yucca extract and lecithin, respectively.

\section{Results and Discussion}

All the evaluated films were visually homogeneous with no phase separation and the average thickness obtained was $43.0 \pm 5.0 \mu \mathrm{m}$ for films containing lecithin and $48.6 \pm 8.2 \mu \mathrm{m}$ for films containing yucca extract.

\section{Mechanical properties}

An increase in glycerol concentration, regardless of the concentration and type of surfactant, decreased TS (Figure 1), due to increased mobility of the polymeric matrix. On the other hand, only for high plasticizer concentration (30g of plasticizer $/ 100 \mathrm{~g}$ of protein) the increase in surfactant concentration (Yucca extract or lecithin) resulted in a decrease of TS (Figure 1), possibly due to greater interaction between hydrophilic part of surfactants and glycerol. Rodríguez et al. ${ }^{[22]}$ found similar behavior in films based on potato starch, glycerol and surfactants, where an increasing in the plasticizer concentration resulted in a significant decrease in TS. These authors observed a synergistic effect between glycerol and the surfactants used (Tween 20, Span 80 and soy lecithin) reporting that films containing high concentrations of surfactants, and low amounts of glycerol, showed plastic behavior, with low values of TS and high percentage of elongation. According to these authors, the hydrophilic part of the surfactants could be interacting with glycerol to facilitate its insertion in the polymeric matrix.

The use of glycerol as plasticizer produced films with maximum of $52.3 \%$ and $41.2 \%$ of elongation, when associated with yucca extract and lecithin, respectively (Table 1), being higher than the values observed when these surfactants were used in combination with hydrophobic plasticizers ${ }^{[15,16]}$. Higher elongations, compared to those obtained in this work, have been reported previously in the literature, combining gelatin and glycerol, as plasticizer agent, for film production without the addition of surfactants ${ }^{[5,23]}$. The results confirm the absence of plasticization due to the inclusion of the surfactants used, as previously observed when films based on gelatin and the same surfactants, were produced and characterized ${ }^{[24]}$.

Table 1. Effect of surfactants (lecithin and yucca extract) and plasticizer glycerol concentrations on the elongation, solubility and moisture content of gelatin-based films.

\begin{tabular}{|c|c|c|c|c|c|c|c|}
\hline \multirow[t]{2}{*}{$\mathbf{S}_{\mathrm{C}}{ }^{1}$} & \multirow[t]{2}{*}{$\mathbf{G}_{\mathrm{C}}^{2}$} & \multicolumn{2}{|c|}{ Elongation $(\%)$} & \multicolumn{2}{|c|}{ Solubility (\%) } & \multicolumn{2}{|c|}{ Moisture content (\%) } \\
\hline & & Yucca extract & Lecithin & Yucca extract & Lecithin & Yucca extract & Lecithin \\
\hline \multirow{3}{*}{10} & 10 & $9.7 \pm 1.5^{\mathrm{Ac}}$ & $10.5 \pm 0.6^{\mathrm{Ac}}$ & $38.2 \pm 3.0^{\mathrm{Aa}}$ & $37.4 \pm 2.9^{\mathrm{Aa}}$ & $10.1 \pm 4.2^{\mathrm{Aa}}$ & $9.8 \pm 0.8^{\mathrm{Aa}}$ \\
\hline & 20 & $9.3 \pm 0.1^{\mathrm{Ac}}$ & $9.6 \pm 0.4^{\mathrm{Ac}}$ & $41.0 \pm 3.4^{\mathrm{Aa}}$ & $55.2 \pm 4.4^{\mathrm{Aa}}$ & $7.2 \pm 0.5^{\mathrm{Aa}}$ & $6.4 \pm 2.0^{\mathrm{Ab}}$ \\
\hline & 30 & $31.4 \pm 3.7^{\mathrm{Ab}}$ & $28.9 \pm 3.5^{\mathrm{Ab}}$ & $41.6 \pm 2.0^{\mathrm{Aa}}$ & $38.7 \pm 1.4^{\mathrm{Aa}}$ & $9.5 \pm 1.1^{\mathrm{Aa}}$ & $7.7 \pm 1.1^{\mathrm{Bab}}$ \\
\hline \multirow{3}{*}{20} & 10 & $9.8 \pm 1.2^{\mathrm{Ac}}$ & $8.7 \pm 0.5^{\mathrm{Ac}}$ & $41.7 \pm 0.7^{\mathrm{Aa}}$ & $44.6 \pm 4.4^{\mathrm{Aa}}$ & $7.5 \pm 1.3^{\mathrm{Aa}}$ & $8.0 \pm 1.5^{\mathrm{Aab}}$ \\
\hline & 20 & $8.7 \pm 0.4^{\mathrm{Ac}}$ & $8.5 \pm 0.3^{\mathrm{Ac}}$ & $44.4 \pm 2.6^{\mathrm{Aa}}$ & $43.8 \pm 0.5^{\mathrm{Aa}}$ & $8.6 \pm 0.6^{\mathrm{Aa}}$ & $7.6 \pm 0.9^{\mathrm{Bab}}$ \\
\hline & 30 & $25.4 \pm 7.2^{\mathrm{Bb}}$ & $41.2 \pm 3.1^{\mathrm{Aa}}$ & $40.5 \pm 5.0^{\mathrm{Aa}}$ & $46.9 \pm 7.6^{\mathrm{Aa}}$ & $10.3 \pm 0.7^{\mathrm{Aa}}$ & $8.9 \pm 0.7^{\mathrm{Bab}}$ \\
\hline \multirow{3}{*}{30} & 10 & $9.5 \pm 0.2^{\mathrm{Ac}}$ & $9.2 \pm 0.7^{\mathrm{Ac}}$ & $39.4 \pm 4.8^{\mathrm{Aa}}$ & $44.9 \pm 1.1^{\mathrm{Aa}}$ & $8.1 \pm 0.9^{\mathrm{Aa}}$ & $7.4 \pm 0.1^{\mathrm{Aab}}$ \\
\hline & 20 & $8.7 \pm 0.1^{\mathrm{Ac}}$ & $8.2 \pm 0.6^{\mathrm{Ac}}$ & $37.6 \pm 4.8^{\mathrm{Aa}}$ & $41.0 \pm 1.1^{\mathrm{Aa}}$ & $8.5 \pm 1.2^{\mathrm{Aa}}$ & $8.0 \pm 0.9^{\mathrm{Aab}}$ \\
\hline & 30 & $52.3 \pm 2.4^{\mathrm{Aa}}$ & $39.9 \pm 5.5^{\mathrm{Ba}}$ & $42.1 \pm 3.8^{\mathrm{Aa}}$ & $36.5 \pm 8.9^{\mathrm{Aa}}$ & $7.2 \pm 2.2^{\mathrm{Aa}}$ & $6.5 \pm 1.0^{\mathrm{Ab}}$ \\
\hline
\end{tabular}

${ }^{1} \mathrm{~S}_{\mathrm{C}}$ Surfactant concentration $\left(\mathrm{g} / 100 \mathrm{~g}\right.$ of plasticizer); ${ }^{2} \mathrm{G}_{\mathrm{C}}$ : Glycerol concentration $\left(\mathrm{g} / 100 \mathrm{~g}\right.$ of protein), ${ }^{\mathrm{a}, \mathrm{b}}$ Average \pm Standard deviation. Lowercase letters at same column and capital letters at same line with different letters are significantly different $(p \leq 0.05)$. 


\section{Water vapor permeability (WVP)}

The lowest values for WVP were observed with films containing $30 \mathrm{~g}$ of surfactant/100 g plasticizer and $20 \mathrm{~g}$ glycerol $/ 100 \mathrm{~g}$ protein, showing WVP values of 0.14 and $0.15 \mathrm{~g} \mathrm{~mm} / \mathrm{m}^{2} \mathrm{~h} \mathrm{kPa}$, for films containing yucca extract and lecithin, respectively (Figure 2). When 10 or $20 \mathrm{~g}$ of surfactant/100 $\mathrm{g}$ of plasticizer were used, regardless of glycerol concentration associated (data not showed), WVP didn't show significant differences, varying between 0.22 to $0.29 \mathrm{~g} \mathrm{~mm} / \mathrm{m}^{2} \mathrm{~h} \mathrm{kPa}$, and from 0.21 and $0.24 \mathrm{~g} \mathrm{~mm} / \mathrm{m}^{2} \mathrm{~h} \mathrm{kPa}$ for films containing yucca extract or lecithin, respectively.

The use of glycerol in film formulations, usually decrease the intermolecular attraction, increasing the polymeric mobility and also the migration of molecules of water vapor through the film ${ }^{[25,26]}$. However, the addition of substances with hydrophobic characteristics, such as the surfactants used in this study, allowed the reduction of WVP at intermediate concentration of glycerol $(20 \mathrm{~g}$ plasticizer/100 $\mathrm{g}$ protein) indicating that when associated with surfactants, moderate amounts of glycerol can act as a barrier to water vapor. The WVP decrease with the incorporation of substances of non polar nature was observed previously ${ }^{[27,28]}$. A decrease in WVP due

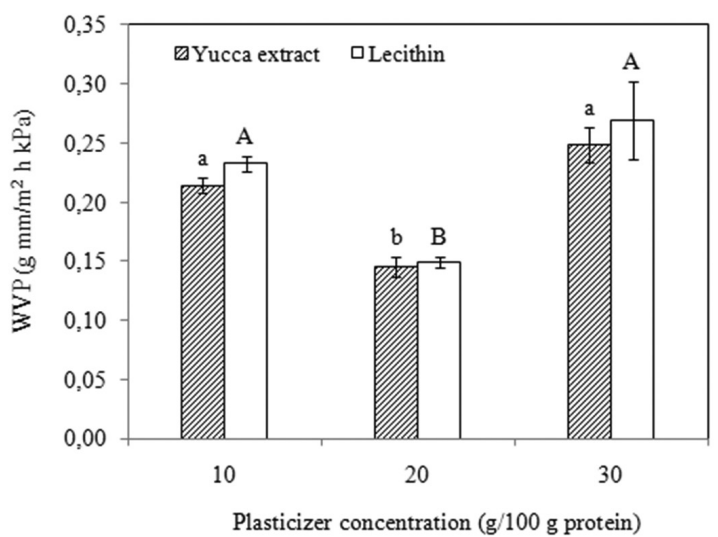

Figure 2. Water vapor permeability of films with different concentration of plasticizer and surfactant. Averages followed by lowercase letters and capital letters represent significant differences $(p \leq 0.05)$, for yucca extract and lecithin, respectively. to the inclusion of surfactants was also observed by Rodríguez et al. ${ }^{[22]}$ in films based on starch, with WVP values ranging between 1 to $2.5 \mathrm{~g} \mathrm{~mm} / \mathrm{m}^{2} \mathrm{~h} \mathrm{kPa}$.

\section{Solubility in water and moisture content}

The concentrations of surfactants and plasticizers evaluated did not show significant differences $(p>0.05)$ in the solubility values and, when comparing the difference between the surfactants, for the same formulation, there were also no significant differences between them (Table 1). The percentage of solubility ranged from 36.5 to $44.4 \%$ for films containing yucca extract, and from 36.5 to $55.2 \%$ for films containing lecithin. The moisture content of the films containing yucca or lecithin also showed no significant differences due to different concentrations of glycerol and surfactants evaluated, with values ranging between approximately $6-10 \%$ for moisture content (Table 1).

It was expected that the inclusion of compounds with hydrophobic characteristics could reduce the solubility of the films, or the addition of the plasticizer with hydrophilic nature could promote the increase in solubility values, but these behaviors were not observed in this study. Gontard et al. ${ }^{[19]}$ suggested that the increase in solubility due to the addition of compounds with hydrophobic characteristics is due to the breakage of intermolecular bonds of the protein network, and subsequent formation of weak interactions with hydrophobic substances, resulting in structural instability and making films, in that case, more soluble.

The combined interaction of surfactant, regardless of the type evaluated, with the glycerol, produced partially soluble films, although, the addition of these compounds has produced films significantly less soluble, compared to gelatin films, that showed solubility value of $88 \%{ }^{[27]}$.

\section{Opacity and $b^{*}$ value}

The opacity of simple films based on gelatin was around $12.7 \%{ }^{[29]}$, and comparatively, the inclusion of surfactants produced more opaque films (Table 2).

Opacity increase depended on surfactant type; films containing lecithin were slightly more opaque than films made with yucca extract, however, the addition

Table 2. Effect of surfactants (lecithin and yucca extract) and plasticizer glycerol concentrations on the opacity and b* value of gelatinbased films.

\begin{tabular}{|c|c|c|c|c|c|}
\hline \multirow[t]{2}{*}{$\overline{S_{\mathrm{C}}{ }^{1}}$} & \multirow[t]{2}{*}{$\mathbf{G}_{\mathrm{C}}^{2}$} & \multicolumn{2}{|c|}{ Opacity (\%) } & \multicolumn{2}{|c|}{$b^{*}$ value } \\
\hline & & Yucca extract & Lecithin & Yucca extract & Lecithin \\
\hline \multirow{3}{*}{10} & 10 & $12.7 \pm 0.2^{\mathrm{Ab}}$ & $12.9 \pm 0.1^{\mathrm{Ae}}$ & $2.9 \pm 0.2^{\mathrm{Ae}}$ & $2.7 \pm 0.0^{\mathrm{Ac}}$ \\
\hline & 20 & $13.0 \pm 0.1^{\mathrm{Ab}}$ & $13.2 \pm 0.1^{\mathrm{Ade}}$ & $3.8 \pm 0.2^{\mathrm{Ad}}$ & $2.7 \pm 0.1^{\mathrm{Ac}}$ \\
\hline & 30 & $12.9 \pm 0.1^{\mathrm{Bb}}$ & $13.3 \pm 0.0^{\text {Ade }}$ & $4.3 \pm 0.4^{\mathrm{Ad}}$ & $2.9 \pm 0.1^{\mathrm{Bc}}$ \\
\hline \multirow{3}{*}{20} & 10 & $12.9 \pm 0.1^{\mathrm{Ab}}$ & $13.3 \pm 0.1^{\mathrm{Ade}}$ & $3.7 \pm 0.5^{\text {Ade }}$ & $2.8 \pm 0.1^{\mathrm{Bc}}$ \\
\hline & 20 & $12.9 \pm 0.1^{\mathrm{Bb}}$ & $13.8 \pm 0.1^{\mathrm{Abc}}$ & $5.1 \pm 0.2^{\mathrm{Ac}}$ & $3.9 \pm 0.1^{\mathrm{Bb}}$ \\
\hline & 30 & $12.9 \pm 0.0^{\mathrm{Bb}}$ & $14.1 \pm 0.1^{\mathrm{Ab}}$ & $6.4 \pm 0.3^{\mathrm{Ab}}$ & $4.2 \pm 0.2^{\mathrm{Bab}}$ \\
\hline \multirow{3}{*}{30} & 10 & $13.2 \pm 0.1^{\mathrm{Aab}}$ & $13.4 \pm 0.1^{\text {Acd }}$ & $4.1 \pm 0.3^{\mathrm{Ad}}$ & $2.9 \pm 0.2^{\mathrm{Bc}}$ \\
\hline & 20 & $12.9 \pm 0.1^{\mathrm{Bb}}$ & $14.8 \pm 0.1^{\mathrm{Aa}}$ & $6.2 \pm 0.2^{\mathrm{Ab}}$ & $4.5 \pm 0.2^{\mathrm{Ba}}$ \\
\hline & 30 & $13.7 \pm 0.4^{\mathrm{Aa}}$ & $14.5 \pm 0.3^{\mathrm{Aa}}$ & $8.1 \pm 0.7^{\mathrm{Aa}}$ & $4.1 \pm 0.3^{\mathrm{Bab}}$ \\
\hline
\end{tabular}

${ }^{1} \mathrm{~S}_{\mathrm{C}}$ Surfactant concentration (g/100 g of plasticizer); ${ }^{2} \mathrm{G}_{\mathrm{C}}$ : Glycerol concentration (g/100 g of protein), a,bAverage \pm Standard deviation. Lowercase letters at same column and capital letters at same line with different letters are significantly different $(p \leq 0.05)$. 
of surfactants, regardless of the type used, did not significantly alter the opacity values. The increased levels of surfactant tend to increase $b^{*}$ values, being the more pronounced effect observed for films containing yucca extract. The same effect observed before in gelatin-based films added with the same surfactants ${ }^{[24]}$. Tween 80 was used as emulsifier into carboxymethyl cellulose films containing glycerol and oleic acid, and it was observed that an increasing on oleic acid content increased $b$ values of the films. This effect could be attributed to the coalescence and creaming of lipids droplets during the film drying ${ }^{[30]}$.
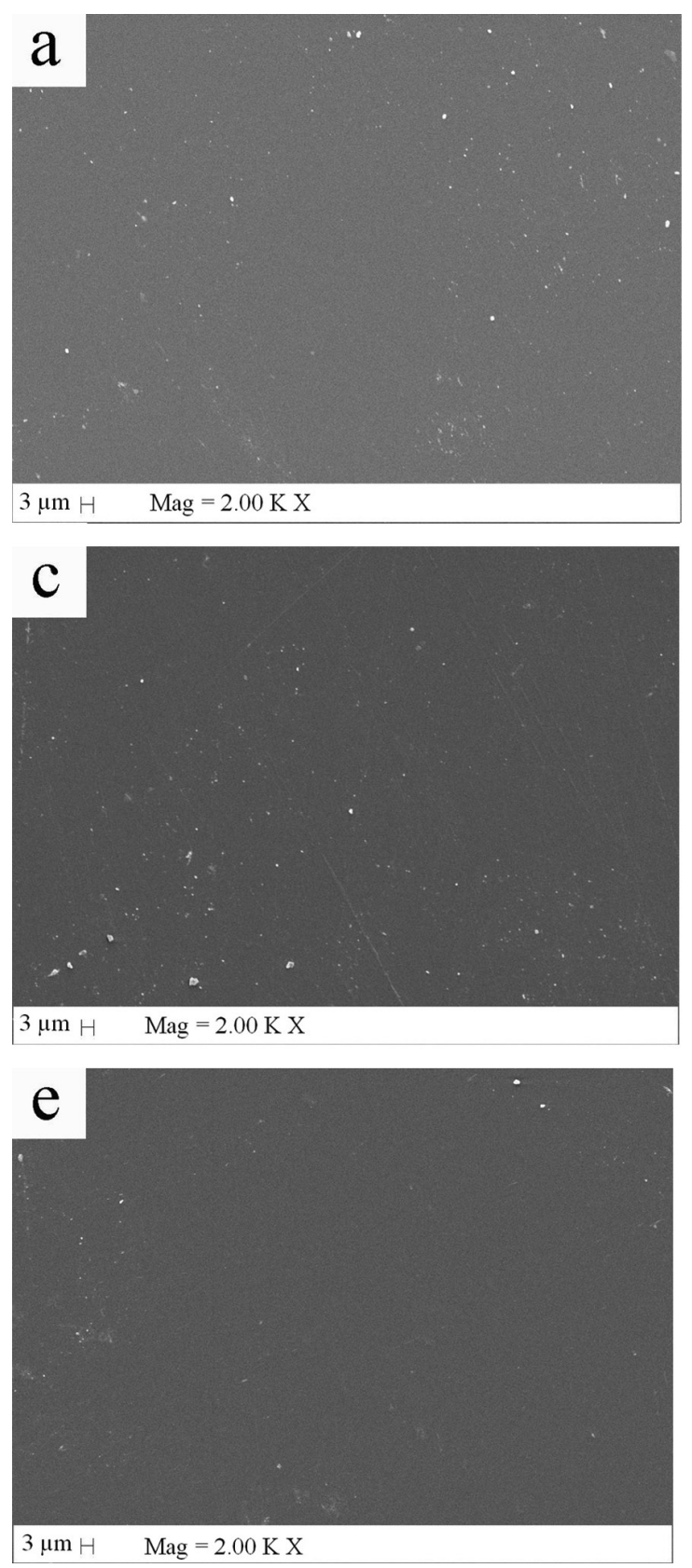

\section{Scanning electron microscopy}

For the study of the morphology of the films, formulations with lower concentrations of plasticizer (10\%) and surfactant (10\%), higher concentrations of plasticizer $(30 \%)$ and surfactant $(30 \%)$ and formulation that resulted in films with the lowest WVP values (20\% of plasticizer and $30 \%$ of surfactant) were chosen. The films surfaces micrographs produced with both, yucca extract (Figures 3a, c, e) and lecithin (Figures 4a, c, e) showed no significant differences due to increased concentrations of plasticizer and/or surfactant. The surfaces were

\section{b}

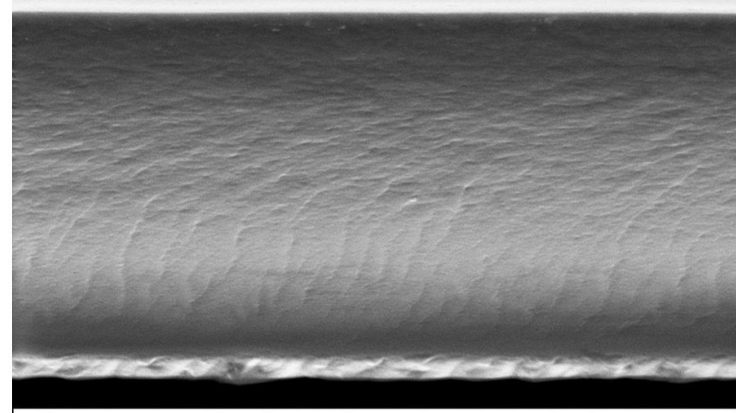

$3 \mu \mathrm{m} \longmapsto \quad \mathrm{Mag}=5.00 \mathrm{~K} \mathrm{X}$
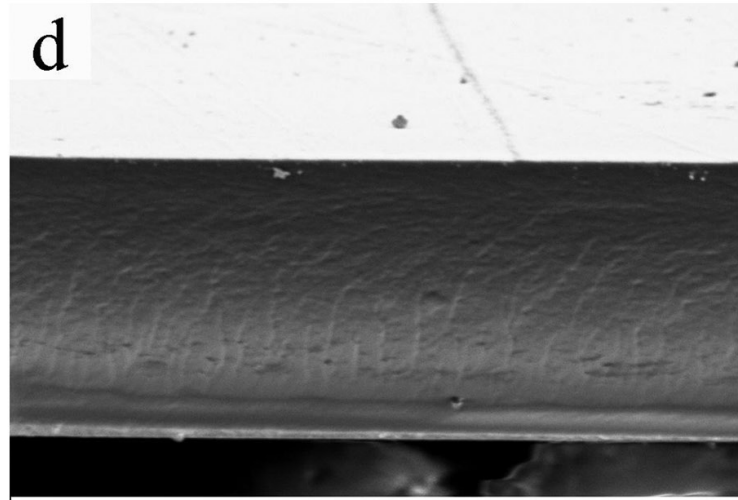

$3 \mu \mathrm{m} \longmapsto \quad \mathrm{Mag}=5.00 \mathrm{~K} \mathrm{X}$
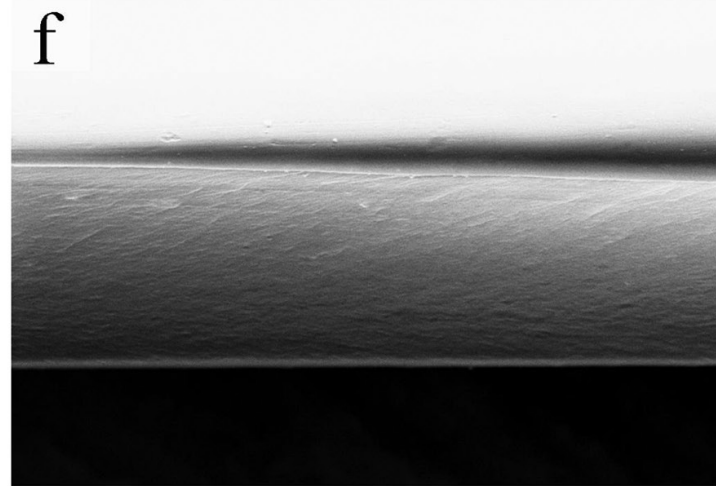

$3 \mu \mathrm{m} \longmapsto \quad \mathrm{Mag}=5.00 \mathrm{~K} \mathrm{X}$

Figure 3. SEM micrographs (bars $=3 \mu \mathrm{m}$ ) of the surface (left column) and internal structures (right column) of gelatin-based films containing yucca extract and glycerol. (a) and (b) $10 \%$ plasticizer and $10 \%$ yucca extract; (c) and (d) $20 \%$ plasticizer and $30 \%$ yucca extract; (e) and (f) $30 \%$ plasticizer and $30 \%$ yucca extract. 

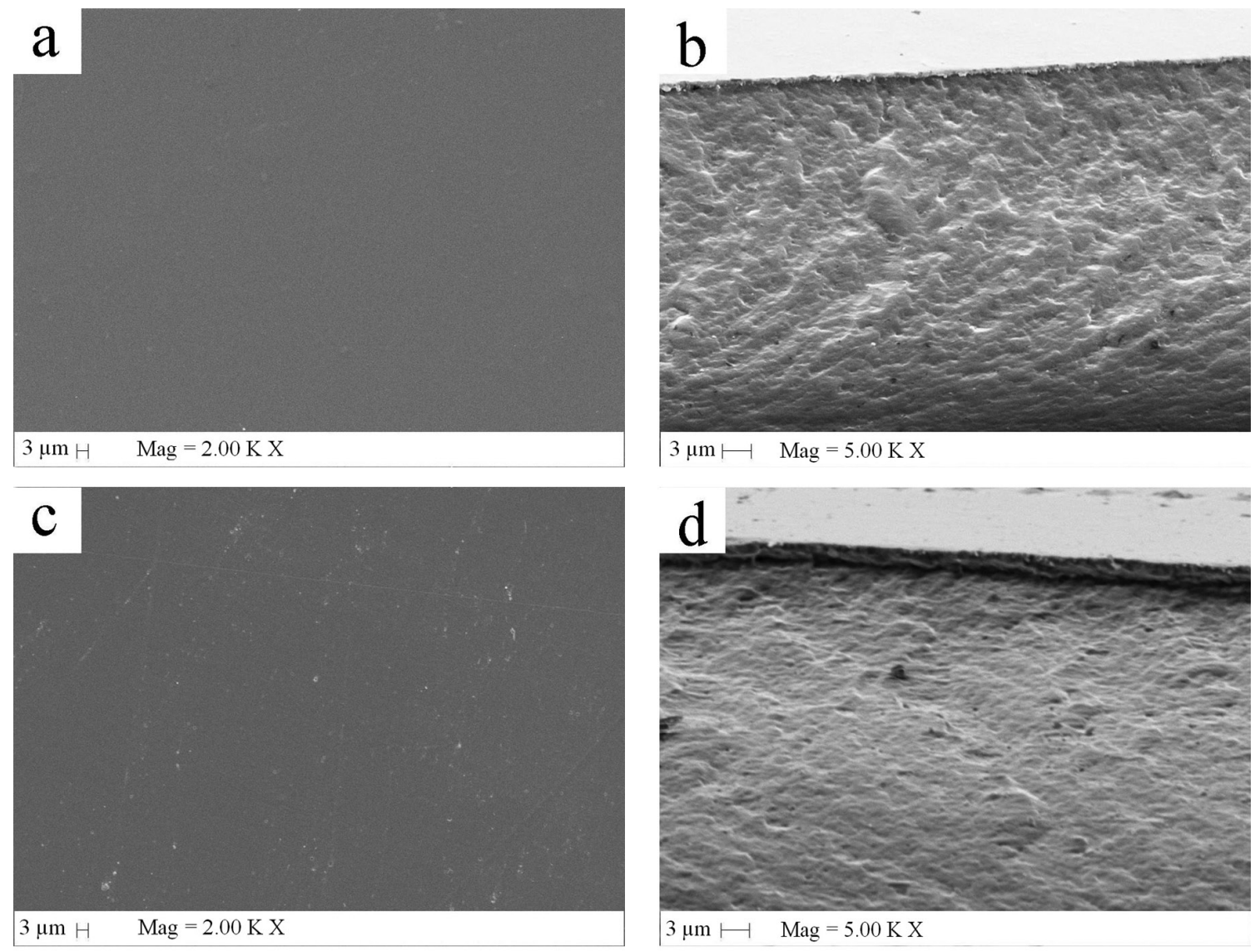

$3 \mu \mathrm{m} \longmapsto \quad \mathrm{Mag}=5.00 \mathrm{KX}$

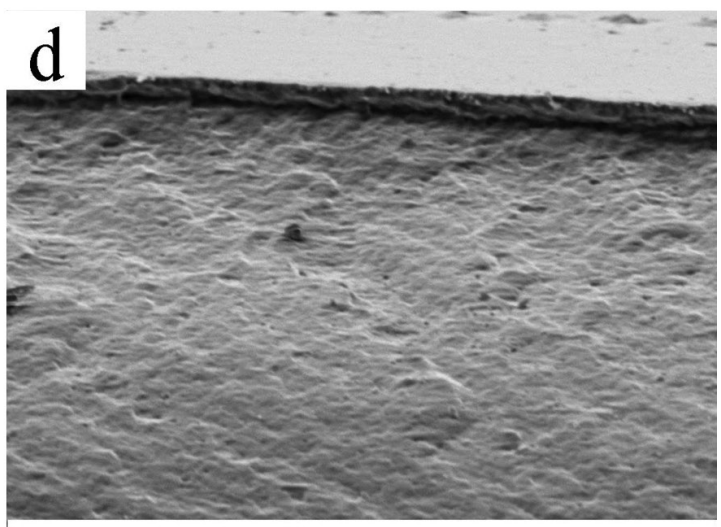

$3 \mu \mathrm{m} \longmapsto \quad M a g=5.00 \mathrm{KX}$
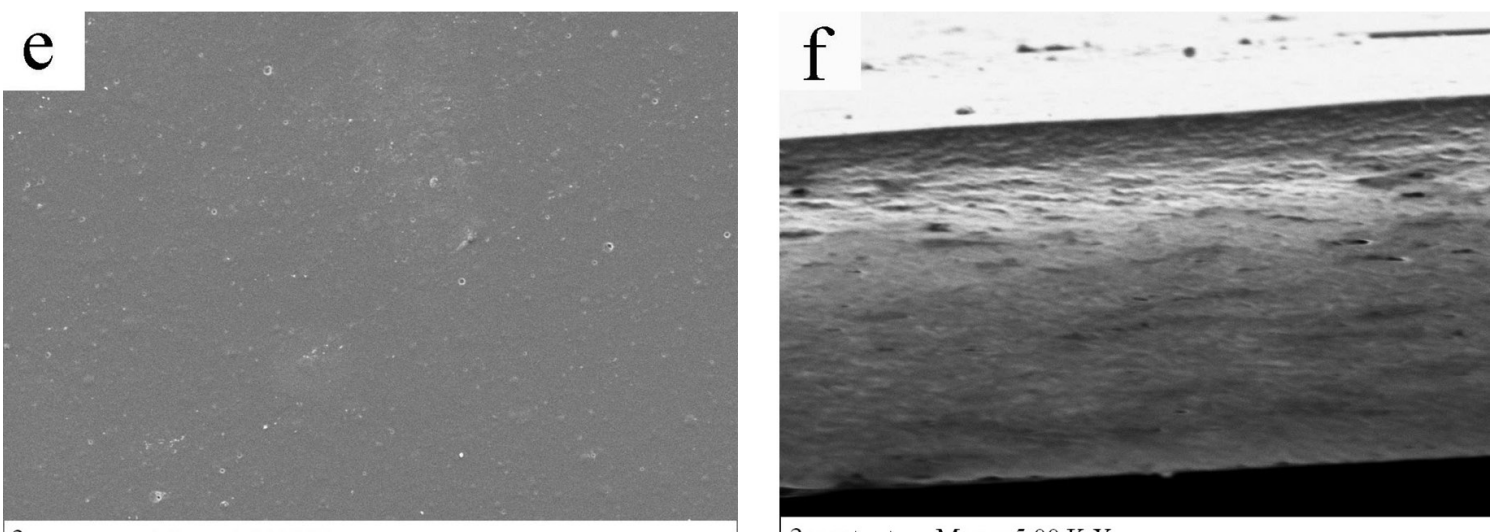

$3 \mu \mathrm{m} \mathrm{H} \quad \mathrm{Mag}=2.00 \mathrm{KX}$

$3 \mu \mathrm{m} \longmapsto \quad \mathrm{Mag}=5.00 \mathrm{KX}$

Figure 4. SEM micrographs (bars $=3 \mu \mathrm{m}$ ) of the surface (left column) and internal structures (right column) of gelatin-based films containing soy lecithin and glycerol. (a) and (b) 10\% plasticizer and 10\% lecithin; (c) and (d) 20\% plasticizer and 30\% lecithin; (e) and (f) $30 \%$ plasticizer and $30 \%$ lecithin.

homogeneous and regular, with no brittle zones, and no superficial globules, indicating that there was good compatibility and incorporation of the compounds added to the protein matrix.

It is observed that in the cross sections of films containing yucca extract (Figures $3 \mathrm{~b}, \mathrm{~d}, \mathrm{f}$ ) there are no pores, no indication of phase separation, and a compact and homogeneous structure, regardless of the concentrations of surfactant or plasticizer evaluated. For films containing lecithin, in cross sections (Figures 4b, d, f), it was observed a compact structure, but more irregular when compared to the inner sections of the films made with yucca extract.

\section{Conclusions}

The use of glycerol as plasticizer produced values of elongation of $52.3 \%$ and $41.2 \%$ for films based on gelatin, containing yucca extract and lecithin, respectively. However, the values of tensile strength were significantly reduced for these conditions reproducing the behavior reported in the literature, additionally, the combination 
of glycerol and plasticizers produced lowering of WVP, an opposite effect to that observed in the literature for films based on gelatin and glycerol without surfactants. In the intermediate concentration of glycerol $(20 \mathrm{~g}$ plasticizer/100 g protein), the simultaneous addition of surfactants has reduced the WVP for minimum values of 0.14 and $0.15 \mathrm{~g} \mathrm{~mm} / \mathrm{m}^{2} \mathrm{~h} \mathrm{kPa}$, respectively, for films containing yucca extract and lecithin. The films showed homogeneous surface and inner section compact and cohesive.

Films reasonably strong, flexible and with low permeability to water vapor, were obtained in this study, indicating that the addition of new surfactants associated to plasticizers normally used in the production of edible films/biodegradable, should be investigated.

\section{Acknowledgments}

The authors are grateful to Gelita do Brasil Ltda (gelatin), to Beraca Sabará Químicos e Ingredientes Ltda (yucca extract), and to Caramuru (soy lecithin). We are also grateful to FAPESP (process $n^{\circ}$ 2006/00431-8) and to the scholarship to the first author (process $n^{\circ} 2010 / 01304-5$ ).

\section{References}

1. Krochta, J. M. - "Proteins as raw materials for films and coatings: definitions, status, and opportunities", CRC Press, Boca Raton (2002).

2. Fabra, M. J.; Jiménez, A.; Atarés, L.; Talens, P. \& Chiralt, A. - Biomacromolecules, 10, p.1500 (2009). http://dx.doi. org/10.1021/bm900098p

3. Pérez-Gago, M. B. \& Krochta, J. M. J. - Agr. Food. Chem., 49, p.996 (2001). http://dx.doi.org/10.1021/ jf000615f

4. Pommet, M.; Redl, A.; Morel, M. H. \& Guilbert, S. - Polymer, 44, p.115 (2003). http://dx.doi.org/10.1016/ S0032-3861(02)00746-2

5. Thomazine, M.; Carvalho, R. A. \& Sobral, P. J. A. - J. Food Sci., 70, p.172 (2005). http://dx.doi. org/10.111/j.1365-2621.2005.tb07132.x

6. Arvanitoyannis, I. - "Formation and properties of collagen and gelatin films and coatings", CRC Press, Boca Raton, FL (2002).

7. Banker, G. S. - J. Pharm. Sci., 55, p.81 (1966). http:// dx.doi.org/10.1002/jps.2600550118

8. McHugh, T. H. \& Krochta, J. M. - Food Tech., 48, p.97 (1994).

9. Schneider, M. - "Phospholipids", Marcel Dekker Inc., New York (1997).

10. Güçlü-Üstündag, O. \& Mazza, G. - Crit. Rev. Food. Sci., 47, p.231 (2007). http://dx.doi. org/10.1080/10408390600698197

11. Cheeke, P. R. - J. Anim. Sci., 77, p.1 (2000). http://jas.fass. org/content/77/E-Suppl/1.9
12. Oleszek, W.; Sitek, M.; Stochmal, A.; Piacente, S.; Pizza, C. \& Cheeke, P. - J. Agric. Food Chem., 49, p.4392 (2001). http:// dx.doi.org/10.1021/jf010598

13. Oleszek, W.; Sitek, M.; Stochmal, A.; Piacente, S.; Pizza, C. \& Cheeke, P. - J. Agric. Food Chem., 49, p.747 (2001). http:// dx.doi.org/10.1021/jf001056f

14. Piacente, S.; Montoro, P.; Oleszek, W. \& Pizza, C. - J. Nat. Prod., 67, p.882 (2004). http://dx.doi.org/10.1021/ np030369c

15. Andreuccetti, C.; Carvalho, R. A. \& Grosso, C. R. F. - Food Res. Int., 42, p.1113 (2009). http://dx.doi.org/10.1016/j. foodres.2009.05.010

16. Andreuccetti, C.; Carvalho, R. A. \& Grosso, C. R. F. - Food Res. Int., 43, p.1710 (2010). http://dx.doi.org/10.1016/j. foodres.2010.05.013

17. American Society for Testing and Materials. - "ASTM D882-95", Am. Soc. Test. Mater. (1995).

18. American Society for Testing and Materials. - "ASTM E96-95”, Am. Soc. Test. Mater., Philadelphia (1995).

19. Gontard, N.; Duchez, C.; Cuq, J-L. \& Guilbert, S. - J. Food Sci. Tech., 29, p.39 (1994). http://dx.doi. org/10.1111/j.1365-2621.1994.tb02045.x

20. American Society for Testing and Materials. - "ASTM D523”, Am. Soc. Test. Mater., Philadelphia (1999).

21. American Society for Testing and Materials. - "ASTM D1925", Am. Soc. Test. Mater. (1995).

22. Rodríguez, M.; Osés, J.; Ziani, K.; Maté, J. I. - Food Res. Int., 39, p.840 (2006). http://dx.doi.org/10.1016/j. foodres.2006.04.002

23. Vanin, F. M.; Sobral, P. J. A.; Menegalli, F. C.; Carvalho, R. A. \& Habitante, A. M. Q. B. - Food Hydrocolloid., 19, p.889 (2005). http://dx.doi.org/10.1016/j.foodhyd.2004.12.003

24. Andreuccetti, C.; Carvalho, R.A.; Galicia-Garcia, T.; Martínez-Bustos, F. \& Grosso, C. R. F. - J. Food Eng., 103, p.129 (2011). http://dx.doi.org/10.1016/j. foodeng.2010.10.007

25. Cho, S. Y. \& Rhee, C. - Food Sci. Technol., 35, p.151 (2002). http://dx.doi.org/10.1006/jstl.2001.0829

26. Cao, N.; Fu, Y. \& He, J. - Food Hydrocolloid., 21, p.1153 (2007). http://dx.doi.org/10.1016/j.foodhyd.2006.09.001

27. Pérez-Mateos, M.; Montero, P. \& Gómez-Guillén, M. C. - Food Hydrocolloid., 23(1): p.53 (2009). http://dx.doi. org/10.1016/j.foodhyd.2007.11.011

28. Chen, C-H.; Kuo, W-S. \& Lai, L-S. - Food Hydrocolloid., 23, p.714 (2009). http://dx.doi.org/10.1016/ jfoodhyd.2008.06.006

29. Bertan, L. C.; Tanada-Palmu, P. S.; Siani, A. C. \& Grosso, C. R. F. - Food Hydrocolloid., 19, p.73 (2005). http:// dx.doi.org/10.1016/j.foodhyd.2004.04.017

30. Ghanbarzadeh, B. \& Almasi, H. - Int. J. Biol. Macrom., 48, p.44 (2011). http://dx.doi.org/10.1016/j. ijbiomac.2010.09.014

Received: 09/05/12

Revised: $29 / 11 / 12$

Accepted: 15/01/13 